Jurnal Basicedu Volume 4 Nomor 2 April 2020 Hal. 419-425

JURNAL BASICEDU

Research \& Learning in Elementary Education

https://jbasic.org/index.php/basicedu

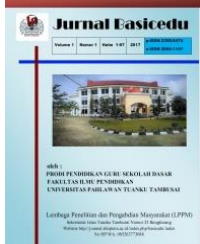

\title{
PENGEMBANGAN BAHAN AJAR PEMBELAJARAN TEMATIK DENGAN MENGGUNAKAN METODE VISUAL STORYTELLING DI SEKOLAH DASAR
}

\author{
Syahda Puspita Husada ${ }^{1}$, Taufina ${ }^{2,}$ Ahmad Zikri ${ }^{3}$ \\ Universitas Negeri Padang, Sumatera Barat, Indonesia ${ }^{1,2,3}$ \\ e-mail: Syahda@gmail.com ${ }^{1}$, taufina_taufik@yahoo.co.id ${ }^{2}$, zikria79@yahoo.com $^{3}$
}

\begin{abstract}
Abstrak
Penelitian ini bertujuan untuk menghasilkan bahan ajar tematik dengan metode storytelling untuk pendidik kelas V yang valid, praktis, dan efektif. Penelitian ini menggunakan penelitian pengembangan berdasarkan model 4D (Define, Design, Develop dan Disseminate). Kevalidan dilhat dari segi isi, bahasa, penyajian, kegrafikaan dan RPP, keseluruhan 85. \% dengan kategori valid. Pratikalitas bahan ajar dilihat dari respon pendidik, $90 \%$ respon peserta didik $90 \%$. Dapat disimpulkan bahwa bahan ajar tematik menggunakan metode visual storytelling yang dikembangkan layak digunakan di kelas V SD.
\end{abstract}

Kata Kunci: Bahan Ajar, Pembelajaran Tematik, Metode Visual Storytelling

\begin{abstract}
This study aims to produce thematic teaching materials with storytelling methods for class $\mathrm{V}$ educators that are valid, practical, and effective. This study uses development research based on the 4D model (Define, Design, Develop and Disseminate). Validity is seen in terms of content, language, presentation, graphic and lesson plans, overall $85 . \%$ with valid categories. The practicality of teaching materials can be seen from the responses of educators, $90 \%$ of students' responses $90 \%$. It can be concluded that the thematic teaching materials using the visual storytelling method developed are suitable for use in grade V elementary school.
\end{abstract}

Keywords: Teaching Material, Thematic Learning, Visual Storytelling methode

@ Jurnal Basicedu 2020

Corresponding author :

Address : Air Tawar Padang

ISSN 2580-3735 (Media Cetak)

Email : Syahda@gmail.com

ISSN 2580-1147 (Media Online)

Phone : 089531307164 


\section{PENDAHULUAN}

Guru memiliki tugas merencanakan, melaksanakan, dan mengevaluasi proses pembelajaran. Proses pembelajaran tersebut tidak terlepas dari pentingnya peran bahan ajar. Guru harus mampu mengembangkan bahan ajar dari pemerintah sebagai penunjang keberhasilan Kurikulum 2013 (Kemendikbud, 2013) Pengembangan bahan ajar sangatlah diperlukan untuk membantu guru maupun siswa. Sehingga, guru hendaknya mampu memfasilitasi dengan baik proses tersebut sesuai kebutuhan siswanya. Salah satu kebutuhan siswa adalah fasilitas berupa bahan ajar .

Mata pelajaran yang perlu diperhatikan dalam pengembangan bahan ajar salah satunya adalah Bahasa Indonesia. Pembelajaran bahasa Indonesia memuat empat kerampilan berbahasa, yaitu mendengarkan, berbicara, membaca, dan menulis (Irawati \& Elmubarok, 2015). Namun, membaca merupakan salah satu keterampilan berbahasa yang sangat penting di samping tiga keterampilan berbahasa lainnya. Hal ini didasarkan karena membaca merupakan sarana untuk mempelajari suatu hal sehingga bisa memperluas pengetahuan dan menggali pesan-pesan tertulis dalam bahan bacaan. Walaupun demikian, membaca bukanlah suatu pekerjaan yang mudah untuk dilakukan dan perlu bimbingan melalui proses pembelajaran yang tepat.

Membaca adalah kegiatan sehari-hari yang sering kita lakukan secara sadar atau tidak sadar melalui penguraian pesan yang mengelilingi kita dalam berbagai bentuk. Membaca adalah proses yang kompleks yang melibatkan berbagai keterampilan (Mayarnimar \& Taufina, 2017) daripada decoding pesan sederhana. Selanjutnya membaca merupakan suatu proses menerjemahkan simbol tulis ke dalam bunyi bahasa yang diubah menjadi lambang tulisan dan bunyi-bunyi (Sapitri,
Mudjiran, \& Taufina, 2019; Taufina \& Chandra, 2017; Taufina, 2017).

Pembelajaran membaca bukan sematamata dilakukan agar peserta didik mampu membaca. Proses pembelajaran membaca memuat banyak kegiatan yang dapat dilakukan pada peserta didik, seperti kegiatan memprediksi teks bacaan, menanggapi teks bacaan, menceritakan kembali secara lisan maupun tulisan, dan lain sebagainya. Dengan demikian dapat disimpulkan bahwa pengembangan bahan ajar membaca merupakan merupakan salah satu faktor penentu keberhasilan sebuah proses pembelajaran.

Bahan ajar digunakan sebagai media transfer informasi atau ilmu dari guru kepada peserta didik. Bahan ajar merupakan segala bahan (baik informasi, alat, maupun teks) yang disususn secara sistematis, yang menampilkan sosok utuh dari kompetensi yang akan dikuasai oleh peserta didik dan digunakan dalam proses pembelajaran dengan tujuan perencanaan dan penelaahan implementasi pembelajaran (Desyandri \& Vernanda, 2017; Irawati \& Elmubarok, 2015; Prastowo, 2013). Bahan ajar merupakan bahanbahan atau materi pembelajaran yang disusun secara sistematis, yang digunakan guru dan peserta didik dalam proses pembelajaran di sekolah.

Bahan ajar yang digunakan sangat menentukan pencapaian setiap kompetensi dasar yang ditetapkan. Bahan ajar yang memenuhi kriteria baik akan melahirkan sebuah proses pembelajaran yang efektif (Irawati \& Elmubarok, 2015). Namun sebaliknya, apabila bahan ajar kurang sesuai dengan kriteria maka yang akan lahir adalah berbagai permasalahan dalam pembelajaran. Selanjutnya bahan ajar merupakan segala bentuk bahan yang digunakan untuk membantu guru dalam melaksanakan proses pembelajaran (Lestariningsih \& Suardiman, 2017). Akan tetapi, bahan ajar yang digunakan hendaknya tidak hanya sekedar membantu proses 
421 Pengembangan Bahan Ajar Pembelajaran Tematik dengan Menggunakan Metode Visual Storytelling di Sekolah Dasar-Syahda Puspita Husada, Taufina, Ahmad Zikri

pembelajaran namun melihat secara utuh ketercapaian kompetensi dasar yang dikembangkan.

Penggunaan bahan ajar merupakan salah satu faktor penentu keberhasilan sebuah proses pembelajaran. Bahan ajar yang memenuhi kriteria baik akan melahirkan sebuah proses pembelajaran yang efektif. Namun sebaliknya apabila bahan ajar yang digunakan kurang sesuai dengan kriteria dan tuntutan kompetensi dasar, maka yang akan di timbulkan adalah berbagai permasalahan dalam pembelajaran.

Berdasarkan hasil observasi yang penulis lakukan di kelas V SD Negeri 28 Rawang Timur Kec. Padang Selatan Kota Padang, penulis menemukan beberapa permasalahan diantaranya: (1) terlihat buku siswa yang digunakan peserta didik kurang operasional. (2) penulis tidak menemukan tujuan pembelajaran tercantum di dalamnya. (3) terdapat ketidaksesuaian jenis teks yang disajikan dengan Kompetensi Dasar (KD) muatan pelajaran Bahasa Indonesia (BI) sebagai penghela muatan pelajaran lain dalam pembelajaran tematik kurikulum 2013.

Mengatasi masalah yang ditemukan, maka perlu dikembangkan bahan ajar yang tepat dengan metode pembelajaran yang sesuai. Penulis memilih mengembangkan bahan ajar dengan menerapkan metode sebagai alternative solusi.

Bahan ajar menggunakan metode Visual Storytelling lebih menarik bagi peserta didik karena eye catching. Penulis juga tertarik mengembangkan ini karena belum banyak artikel maupun buku yang menguraikan penggunaan metode Visual Storytelling pada bahan ajar pembelajaran tematik di sekolah dasar (ChaoFernandez, Román-García, \& Chao-Fernandez, 2017; Rizka Novia Rohmawati, Muslimin Ibrahim, \& Nur Ducha, 2014; Zammit, Gao, \& Evans, 2016).
Visual storytelling merupakan salah satu pembelajaran interaktif menggunakan cerita dan dipadukan melalui cerita (storytelling). Model ini berkembang setelah masuknya era teknologi. Memadukan gambar dan cerita sehingga menarik perhatian anak untuk mendengarkan cerita tersebut.

Berdasarkan pertimbangan tersebut,
penulis hendak melakukan penelitian
pengembangan dengan judul: "Pengembangan Bahan Ajar dalam Pembelajaran Tematik dengan Menggunakan Metode Visual Storytelling di Kelas V SD"

\section{METODE}

Bahan ajar yang dikembangkan menggunakan model pengembangan dengan Pendekatan 4-D, Pendekatan ini dikembangkan oleh Sugiyono (Sugiono, 2007; Sugiyono, 2013). Sugiyono (2009: 404) menjelaskan tahap-tahap Pendekatan 4-D antara lain: pendefinisian (define), perancangan (design), pengembangan (develop), dan penyebaran (disseminate). Akan tetapi, karena keterbatasan tenaga, biaya, dan waktu penulis, tahap penyebaran (disseminate) hanya dilakukan pada skala terbatas yaitu kelas V SDN 28 Rawang Timur yang sesuai dengan kebutuhan penulis.

Pendekatan pengembangan yang dipilih dalam setiap penelitian memiliki kelebihan yang dapat dijadikan sebagai dasar dan acuan dalam pemilihan Pendekatan yang dilakukan. Kelebihan yang dimiliki oleh Pendekatan 4-D antara lain: (1) lebih tepat digunakan sebagai dasar untuk pengembangan bahan ajar, (2) uraiannya terlihat lebih lengkap dan sistematis, dan (3) dalam pengembangannya melibatkan penilaian para ahli, sehingga sebelum dilakukan uji coba di lapangan bahan ajar telah dilakukan revisi berdasarkan penilaian, saran, dan masukan dari para ahli. 
Tahap Pendefinisian ( Define). Tahap ini dilakukan dengan menganalisis tujuan dalam batasan materi pembelajaran yang dikembangkan. Tahap pendefinisian ini mendapatkan syarat-syarat pembelajaran yang sesuai dengan tujuan penelitian yaitu pengembangan bahan ajar membaca permulaan dengan menggunakan fabel. Terdapat tiga langkah yang dilakukan dalam tahap pendefinisian, yaitu:

Analisis kebutuhan disini merupakan analisis kebutuhan bahan ajar. Analisis bertujuan untuk mengetahui masalah dasar yang dibutuhkan dalam pengembangan bahan ajar. Analisis yang dilakukan pada bahan ajar melihat dua aspek utama, yaitu isi teks (content) dan desain (tampilan dan redaksi). Isi teks merupakan ketepatan dan keakuran informasi yang disajikan dalam teks. Sedangkan desain merupakan cara mengungkapkan dan menampilkan bahan sehingga mempunyai tingkat keterbacaan yang menarik dan memotivasi peserta didik.

Analisis Peserta Didik. Analisis peserta didik dilakukan dengan tujuan untuk mengetahui bahan ajar yang disukai peserta didik dengan memperhatikan karakteristik peserta didik. Karakteristik peserta didik yang ditelaah meliputi perkembangan bahasa, keterampilan membaca permulaan, dan latar belakang pengetahuannya (Uno, 2010). Oleh sebab itu analisis peserta didik perlu dilakukan agar bahan ajar tematik yang dikembangkan sesuai dengan tingkah laku dan karakteristik peserta didik. Analisis ini dijadikan sebagai bahan acuan dalam mengembangkan bahan ajar menggunakan metode visual storytelling.

Analisis yang peneliti lakukan dengan melakukan observasi dan wawancara terhadap peserta didik terkait bahan ajar yang diinginkan. Berdasarkan hasil wawancara yang peneliti lakukan dengan beberapa peserta didik, mereka mengungkapkan bahwa bahan ajar yang digunakan kurang menarik bagi peserta didik.

Tahap Perancangan (Desaign). Tahap perancangan adalah merancang bahan ajar kelas $\mathrm{V}$ SD semester satu. Adapun hal-hal yang dirancang dalam pengembangan ini adalah :

a. Bahan ajar di rancang menggunakan kertas A4 dengan fullcolour.

b. Pemilihan gambar sesuai dengan siswa kelas V.

c. Rancangan buku visual storytelling sesuai dengan permbelajaran tematik

Tahap pengembangan (develop). Validitas dilakukan oleh ahli di bidang pembelajaran bahasa yang bertujuan untuk mendapatkan masukan terhadap keseluruhan isi materi yang terdapat dalam rancangan bahan ajar visual storytelling yang sudah dirancang. Selanjutnya divalidasi oleh ahli di bidang desain pembelajaran yang bertujuan untuk mendapatkan masukan mengenai kesesuaian isi teks yang dikembangkan untuk pembelajaran tematik kelas V SD.

Ada dua macam validitas yang digunakan dalam pengembangan bahan ajar, yaitu:

1. Validitas isi (content validity), yaitu apakah bahan ajar yang dirancang sesuai dengan pembelajaran tematik

2. Validitas konstruk (construct validity), yaitu kesesuaian komponen-komponen pengembangan yang sudah ditetapkan.

Praktikalitas Bahan Ajar. Bahan ajar yang digunakan merupakan bahan ajar yang telah divalidasi oleh validator. Uji praktikalitas bahan ajar dilakukan menggunakan angket dan lembar observasi. Observasi dilakukan oleh dua orang pengamat, yaitu guru dan peneliti sendiri. Observer mengamati keterpakaian bahan ajar dalam proses pembelajaran dan mengisi instrumen observasi yang telah disiapkan. observer mengisi angket keterpakaian bahan ajar fabel. Hasil angket ini dijadikan sebagai dasar untuk melakukan 
423 Pengembangan Bahan Ajar Pembelajaran Tematik dengan Menggunakan Metode Visual Storytelling di Sekolah Dasar- Syahda Puspita Husada, Taufina, Ahmad Zikri

perbaikan terhadap bahan ajar yang dikembangkan. Aspek keterlaksanaan pembelajaran dilihat dari hasil pengisian lembar keterlaksanaan RPP oleh dua orang observer.

Efektivitas Bahan Ajar Pembelajaran. Efektivitas dilakukan untuk mengevaluasi bahan ajar telah efektif atau tidaknya. Hal yang dilakukan dengan melihat aktivitas dari pembelajaran.

Tahap Penyebaran (disseminate). Tahap ini merupakan tahap penggunaan bahan ajar yang telah dikembangkan pada subjek lain, misalnya di kelas lain, atau sekolah lain. Tujuannya adalah untuk menguji efektivitas penggunaan bahan ajar tersebut pada subjek yang berbeda. Bahan ajar yang dikatakan efektif jika dapat memberikan hasil yang baik terahadap hasil belajar siswa. Peneliti melakukan penyebaran bahan ajar tematik berbasis Turnamen dalam skala terbatas yaitu di kelas V SDN 28 Rawang Timur.

\section{HASIL DAN PEMBAHASAN}

Validasi ahli isi/materi diperlukan sebagai suatu bentuk evaluasi terhadap isi/materi serta penyajian produk yang telah dikembangkan. Data yang diperoleh berupa data kuantitatif dan kualitatif melalui angket yang diberikan peneliti kepada ahli. Peneliti memberikan angket validasi isi/ materi, dan produk yang dikembangkan. Berdasarkan perhitungan data angket yang diperoleh dari validasi diperoleh sebesar $87 \%$ dengan kategori valid.

Validasi bahasa diperlukan sebagai evaluasi terhadap bahasa yang digunakan dalam bahan ajar yang sudah dikembangkan. Penggunaan bahasa yang efektif dan komunikatif sangatlah penting dalam sebuah bahan ajar membaca permulaan. Validitas bahasa diberikan kepada ahli berupa angket yang menunjukkan perolehan $85 \%$ dengan kategori valid.
Validasi penyajian diperlukan sebagai evaluasi terhadap tampilan bahan ajar membaxa permulaan. Data yang diperoleh berupa data kuantitatif dan kualitatif melalui angket yang diberikan peneliti kepada ahli desain pembelajaran Berdasarkan perhitungan data angket yang diperoleh dari validasi ahli desain menunjukkan perolehan sebesar $83 \%$ dengan kategori valid.

Tingkat praktikalitas melihat sejauh mana peserta didik dapat menggunakan bahan ajar visual storytelling dengan baik. Pratikalitas yang diamati adalah keterlaksaan RPP, angket respon pendidik dan angket respon peserta didik terhadap pratikalitas bahan ajar. Hasil observasi saat uji coba di lapangan sesuai dengan perencanaan yang telah di buat dengan presentase $90 \%$ dengan kategori sangat praktis

Bahan ajar dikatakan efektif apabila memberikan efek atau pengaruh baik terhadap pencapaian tujuan bahan ajar yang dikembangkan. Efektivitas peserta didik dilihat dari hasil belajar peserta didik dalam proses pembelajaran. Hasil analisis data terhadap aktivitas peserta didik ketika proses pembelajaran dengan memperolah hasil 90\% Hasil penelitan ini dapat dilihat pada tabel berikut 1 .

Tabel 1. Hasil Persentase Bahan Ajar

\begin{tabular}{|l|l|l|l|l|}
\hline No & \multicolumn{2}{|c|}{ Aspek } & $\begin{array}{c}\text { Persentase } \\
\%\end{array}$ & $\begin{array}{l}\text { Katego } \\
\text { ri }\end{array}$ \\
\hline 1 & $\begin{array}{l}\text { Validit } \\
\text { as }\end{array}$ & Isi & 87 & $\begin{array}{l}\text { Sangat } \\
\text { valid }\end{array}$ \\
\hline & & Bahasa & 85 & $\begin{array}{l}\text { Sangat } \\
\text { valid }\end{array}$ \\
\hline 2. & $\begin{array}{l}\text { Pratikal } \\
\text { itas }\end{array}$ & $\begin{array}{l}\text { Keterlaksaan } \\
\text { RPP }\end{array}$ & 85 & valid \\
\hline & $\begin{array}{l}\text { Respon } \\
\text { pendidik }\end{array}$ & 95 & $\begin{array}{l}\text { Sangat } \\
\text { praktis }\end{array}$ \\
\hline 3 & $\begin{array}{l}\text { Respon } \\
\text { peserta didik } \\
\text { itas }\end{array}$ & $\begin{array}{l}\text { Aktivitas } \\
\text { praktis }\end{array}$ \\
\hline & & 90 & $\begin{array}{l}\text { Sangat } \\
\text { praktis }\end{array}$ \\
\hline Proses & 87 & $\begin{array}{l}\text { Sangat } \\
\text { tinggi }\end{array}$ \\
pembelajara & $\begin{array}{l}\text { Sangat } \\
\text { tinggi }\end{array}$ \\
\hline
\end{tabular}




\begin{tabular}{|l|l|l|l|l|}
\hline & & n tematik & & \\
\hline & Hasil belajar & 93 & $\begin{array}{l}\text { Sangat } \\
\text { tinggi }\end{array}$ \\
\hline
\end{tabular}

\section{SIMPULAN}

Berdasarkan pengembangan dan uji coba dilakukan dilapangan terhadap bahan ajar, bahwa pengembangan bahan ajar dari aspek validitas menunjukkan bahwa bahan ajar ini sangat valid baik dari segi isi, bahasa, dan konstruk. Hasil validasi ini telah divalidasi oleh pakar dibidang masing-masing ahli dan sudah dikatakan sangat valid untuk digunakan. Sedangkan pratikalitas dikategorikan sangat praktis dilihat dari respon pendidik dan peserta didik.

Hasil efektivitas peserta didik menunjukkan bahwa pengembangan bahan ajar visual storytelling di kelas V SD telah dinyatakan efektif dan telah meningkatkan hasil belajar dan sangat layak digunakan. Bahan ajar yang dikembangkan dapat dimanfaatkan oleh peserta didik sebagai bahan belajar. Peserta didik dianjurkan untuk belajar secara mandiri.

\section{DAFTAR PUSTAKA}

Chao-Fernandez, R., Román-García, S., \& ChaoFernandez, A. (2017). Online Interactive Storytelling As A Strategy For Learning Music And For Integrating Pupils With Hearing Disorders Into Early Childhood Education (Ece). Procedia - Social And Behavioral Sciences, 237(June 2016), 17-22. Https://Doi.Org/10.1016/J.Sbspro.2017.02.00 5

Desyandri, D., \& Vernanda. (2017). Pengembangan Bahan Ajar Tematik Terpadu Di Kelas V Sekolah Dasar Menggunakan Identifikasi Masalah. Seminar Nasional Hdpgsdi Wilayah 4, 163-174.

Irawati, R. P., \& Elmubarok, Z. (2015). Pengembangan Buku Ajar Bahasa Indonesia Tematik Berkarakter Bagi Siswa Sd Melalui Sastra Anak. Jurnal Pendidikan Karakter, 7(1), 81-96.

Kementrian Pendidikan Dan Kebudayaan Republik Indonesia. (2013). Implementasi
Kurikulum.

Permendikbud.

Https://Doi.Org/10.1017/Cbo9781107415324 .004

Lestariningsih, N., \& Suardiman, S. P. (2017). Pengembangan Bahan Ajar TematikIntegratif Berbasis Kearifan Lokal Untuk Meningkatkan Karakter Peduli Dan Tanggung Jawab. Jurnal Pendidikan Karakter.

Https://Doi.Org/10.21831/Jpk.V7i1.15503

Mayarnimar, \& Taufina. (2017). Validity Analysis Of The Vark (Visual, Auditory, Read-Write, And Kinesthetic) Model - Based Basic Reading And Writing Instructional Materials For The 1st Grade Students Of Elementary School. In Social Science, Education And Humanities Research (Vol. 118, Pp. 870874). Https://Doi.Org/10.2991/Icset17.2017.141

Prastowo, A. (2013). Pengembangan Bahan Ajar Tematik. Yogyakarta: Viva Pres.

Rizka Novia Rohmawati, Muslimin Ibrahim, \& Nur Ducha. (2014). Keefektifan Digital Storytelling Dalam Pembelajaran Biologi Untuk Siswa Sma Pada Materi Bioteknologi. Jurnal Mahasiswa Teknologi Pendidikan, 3(3), 522-527.

Sapitri, E., Mudjiran, \& Taufina. (2019). Developing Learning Materials Of Narrative Writing Based On The Thinking Ability Improvement Learning Model For Third Grade Student Of Elementary School. In Social Science, Education And Humanities Research (Vol. 178, Pp. 226-229).

Sugiono. (2007). Metode Penelitian Kuantitatif, And Pendekatan Kuantitatif. "Kualitatif Dan $R \& D$. "Bandung: Alfabeta.

Sugiyono. (2013). Metode Penelitian Pendidikan Pendekatan Kuantitaif, Kualitatif, Dan R\&D. Metode Penelitian Pendidikan Pendekatan Kuantitaif, Kualitatif, Dan R\&D. Https://Doi.Org/10.1007/S13398-014-01737.2

Taufina, \& Chandra. (2017). Developing The Big Questions And Bookmark Organizers (Bqbo) Strategy-Based Literacy Reading Learning Materials In The 4th Grade Of Elementary School. In Social Science, Education And Humanities Research (Vol. 118, Pp. 857864). 17.2017.139

Taufina, M. (2017). Developing Literacy Reading Teaching Materials By Using Big Books As 
425 Pengembangan Bahan Ajar Pembelajaran Tematik dengan Menggunakan Metode Visual Storytelling di Sekolah Dasar- Syahda Puspita Husada, Taufina, Ahmad Zikri

An Effort To Build The 2nd Grade Students' Characters In Elementary School. Atlantis Press, 118, 835-844. Https://Doi.Org/10.2991/Icset-17.2017.136

Uno, H. H. B. (2010). Model Pembelajaran: Menciptakan Proses Belajar Mengajar Yang Kreatif Dan Efektif. Jakarta: Bumi Aksara. Https://Doi.Org/10.1038/Cddis.2011.1

Zammit, J., Gao, J., \& Evans, R. (2016). Capturing And Sharing Product Development Knowledge Using Storytelling And Video Sharing. Procedia Cirp, 56, 440-445. Https://Doi.Org/10.1016/J.Procir.2016.10.08 1 